\title{
Giovanni Pietro Basile, Kants Opus postumum und seine Rezeption, De Gruyter, Berlin 2013, p. 536
}

DOI: http://dx.doi.org/10.12775/RF.2015.016

The so-called Opus Postumum not only occupies a special position among the philosophical works of Immanuel Kant, but also marks an exceptional area within the whole world of research on the philosophy of Kant. Whereas, the vast quantity of papers concerning the main works of Kant exceeded the number possible to acquire and master over the course of a human lifetime long ago, literature dedicated to the Kant's unfinished dissertation on the philosophy of nature (its planned title was The Transition from the Metaphysical Foundations of Natural Science to Physics) is relatively limited. There are two main objective reasons for this peculiar state of affairs. Firstly, the manuscript of the sketches of Kant's dissertation was found and published relatively late. Criticized both then and now, the Prussian Academy of Sciences edition of this text, known henceforth as Opus Postumum, falls between the years 1936 and 1938, so it was released after more than a hundred years of Kant scholarship. Secondly, since the beginning of the publication of the text, Opus Postumum was met with strong opposition from the defenders of the "purity" of critical philosophy, who in the text of the manuscript, seemed to notice Kant's attempts to return to his pre-critical positions. There were even some voices stating that the notes are devoid of any philosophical value, and that they are, at most, interesting material for a biographer and include a testimony of the senile disability of the author's mind. All of this leads to the number of studies devoted to Opus Postumum and, various interpretations of its content, to be relatively smaller than that of Kant's other works. However, at the present stage of research on Kant's philosophy, it is possible to present a synthesis presenting all significant interpretations of Opus Postumum. This task was accomplished by Giovanni Pietro Basile in his monograph.

The structure of the book is very clear and transparent although not uniform. Chapters 1 to 4 represent an account of the scholarship published from 1884 to 1968. The division into periods: 1884-1920, then the $20 \mathrm{~s}$ and $30 \mathrm{~s}$ of the twentieth century, and at the end of the period 
of 1938-1968, is additionally separated by a small section, which is dedicated to "the systematic consideration of an early reception of Opus postumum" (chapter three). It is clearly visible that the method used to discuss this material allowed the author to choose two important events in the history of the reception of Opus postumum as dividing points. These are, firstly, the publication of a comprehensive monograph by Erich Adickes entitled Kants Opus postumum (1920) and, secondly, the completion of the publication of Lehmann's manuscript entitled Opus postumum (1938). The contents of further chapters of Giovanni Pietro Basile's work are also arranged chronologically, but are dominated to a greater extent by a brief discussion of several interpretations of Kant's text offered by major scholars (inter alia: Hoppe, Tuschling, Mathieu, Friedman, Schulze, Förster, Emunds and others). The seventh, eighth and ninth chapters have a completely different layout. As a whole, they constitute an attempt to systematize the issues undertaken in Opus postumum. Of course, at the forefront is an analysis on natural philosophy and the theory of cognition, although the author takes up several other issues such as the problem of the concept of animated nature, the idealistic "turn" in Kant's views, his theory of God, or Kant's discussion with speculative idealism. The ninth chapter (Systematic considerations on reception of Opus Postumum after 1938) is a structural equivalent to the third chapter and ties up everything together. Here, too, the author undertakes an extremely interesting problem of the origins of Kant's dissertation. He also tries to summarize the issues previously discussed by scholars and seen by them from various and, very often, quite different perspectives. However, the way in which he does it still puts him more in the position of a rapporteur rather than a critic. The author maintains his distance and merely reports the views of other authors. This working method has already been the subject of criticism in other reviews of this work, which can be found in the scholarship.

At over four hundred pages long, it could be thought that the overview of the reception of Opus Postumum would be comprehensive enough for any reader, however, Giovanni Pietro Basile's monograph offers much more. The study, in fact, includes an almost one hundred page long appendix that contains the source material (extracts from other writings of Kant, letters and biographical texts) and relevant listings and tables showing the heretofore editions, their content, layout etc. The work is closed with a bibliography (for obvious reasons not very extensive) and an index of names.

One of the main objections which have emerged as a key criticism of the text by Giovanni Pietro Basile is the lack of a clear, specific and independent approach to the Kant's text (Bryan Hall, for example, writes about this). I believe that this allegation is groundless. The discussed book is extremely useful, even if the author does not reveal his own po- 
sition and approach in it. It does not even have to refer to the source text (which was also criticized) to illustrate the various readings it presents. The goal of this book is completely different in that it offers a summary of the history of research on Opus Postumum. This task has been accomplished successfully. In my opinion it is hard to overestimate its value as an introduction to the research on Opus Postumum. Unlike other works of Kant, in respect of which the novice researcher can quite easily get an initial understanding and the basic knowledge necessary for in-depth study, Opus is incredibly more difficult. This is due to the structure of the source text as well as its contents. I think that the study by Giovanni Pietro Basile will become an absolutely necessary "map" for every Opus Postumum beginner researcher, who will willingly and with benefit reach and use this study not only as a source of knowledge about Opus Postumum, but also as an aid to their further, more profound studies.

Tomasz Kupś 